\title{
Ammonium distributions, production, and efflux from backreef sediments, St. Croix, US Virgin Islands*
}

\author{
S. L. Williams ${ }^{1}$, S. M. Yarish ${ }^{1} \&$ I. P. Gill ${ }^{2}$ \\ ${ }^{1}$ Marine Sciences Research Center, State University of New York, Stony Brook, New York 11794, USA** \\ ${ }^{2}$ Department of Geology, Louisiana State University, Baton Rouge, Louisiana 70803, USA
}

\begin{abstract}
Sediments in $<3 \mathrm{~m}$ water depth on Tague Bay backreef, St. Croix, US Virgin Islands, were sampled for grain size, Eh, $\mathrm{pH}$, organic carbon, pore-water ammonium and nitrate + nitrite concentrations, ammonium production, and ammonium and nitrate + nitrite benthic fluxes. Most sampling sites had nutrient-poor, oxidized, coarse sand-sized sediments. Ammonium and nitrate + nitrite concentrations were typically $<5 \mu \mathrm{M}$; organic carbon was $<0.6 \% \mathrm{~g}$ dry weight. High spatial heterogeneity on the scale of $\mathrm{cm}^{2}$ existed in all parameters measured except grain size, which decreased regularly away from the reef. We suggest that the nutrient-poor conditions were maintained by high turbulence in the environment, which would minimize organic input to the sediments and maximize resuspension and oxygenation. This view was supported by ammonification rates (mean $=70 \mu \mathrm{mol}(\mathrm{l} \text { sediment })^{-1} \mathrm{~d}^{-1}$ ) and benthic nitrogen fluxes which were low compared to rates reported from many temperate coastal areas. Benthic nitrogen fluxes were highly variable and averaged $71 \pm 95$ (mean \pm SD) $\mu \mathrm{mol}$ ammonium $\mathrm{m}^{-2} \mathrm{~d}^{-1}$ and $-5 \pm 40 \mu \mathrm{mol}$ nitrate + nitrite $\mathrm{m}^{-2} \mathrm{~d}^{-1}$. Local pockets of reducing sediments with ammonium concentrations $>30 \mu \mathrm{M}$ occurred within the generally low-nutrient environment. Their location was correlated in part to stabilization of sediments by certain benthic microalgae. These areas may be zones of enhanced nitrogen remineralization, benthic nitrogen fluxes, and possibly nitrification coupled to denitrification. Comparison of the range of fluxes predicted from ammonification data to the range of measured fluxes showed both positive and negative deviations. Nitrification coupled to denitrification cannot be ruled out as an explanation for measured fluxes which were lower than the production-predicted fluxes because Eh and $\mathrm{pH}$ conditions were within the environmental limits of denitrifying organisms. Loss of nitrogen via denitrification would be an important process to verify in coral reef ecosystems where conservation of nitrogen apparently is otherwise maximized.
\end{abstract}

\section{INTRODUCTION}

Nitrogen cycling in the sediments of coral reefs has been investigated only recently (DiSalvo 1974, Pigott 1977, Entsch et al. 1983, Risk \& Muller 1983). These studies reported pore-water concentrations of dissolved inorganic nitrogen from sampling sites covering wide areas of within-reef environments, but mostly of the forereef. Nitrogen regeneration is a vitally important aspect of coral reef ecosystem function and yet, to our knowledge, only indirect measurements of nitro-

\footnotetext{
- Contribution No. 473 from Marine Sciences Research Center and No. 148 from West Indies Laboratory

- Present address and address for correspondence: West Indies Laboratory, Teague Bay, Christiansted, St. Croix, USVI 00820
}

gen regeneration in coral reef sediment exist. Pigott (1977) estimated rates of nitrogen regeneration for reef sediments based on a stoichiometric analysis of porewater concentrations while Hines \& Lyons (1982) used sulfate reduction measurements to calculate nitrogen regeneration in a lagoonal-type environment.

Our general objective was to investigate aspects of nitrogen cycling in coral reef sediments in a discrete area of reef to (1) define spatial heterogeneity within the sediments and (2) determine if the area was representative of reef environments previously described. We studied the backreef sediments of Tague Bay barrier reef, located on the northeast shore of St. Croix, US Virgin Islands (Fig. 1) and described previously (Adey 1975, 1978, Adey \& Burke 1976). The backreef area appears biologically barren compared to the reef 


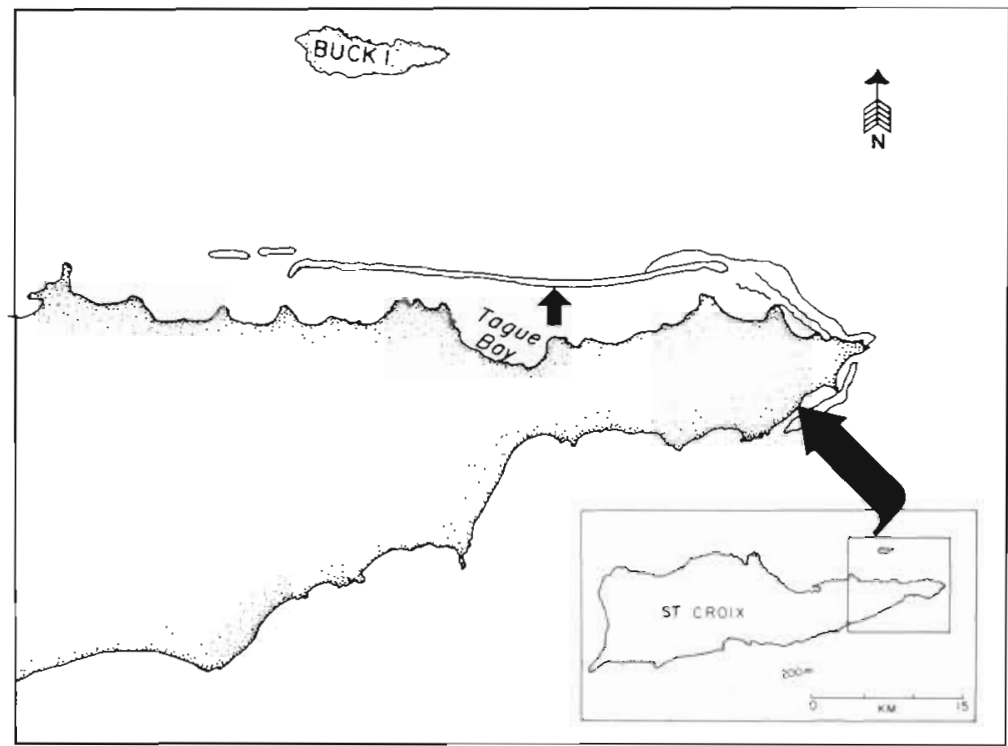

Fig. 1. Map of study site (small arrow) on Tague Bay barrier reef, and inset to show position of site on the northeast shore of St. Croix, US Virgin Islands. Transects were within $20 \mathrm{~m}$ of each other proper and is subjected to much turbulence from surge in the shallow ( 2 to $3 \mathrm{~m}$ ) water and to waves crashing over the reef. The average sea state for the north shore of St. Croix is 3 to 4 with waves rarely below $1 \mathrm{~m}$ high. Yearly from November to February, ocean swells from the northeast create waves of 2 to $3 \mathrm{~m}$ and from August through October tropical waves, storms, or hurricanes with similar or stronger sea conditions occur frequently, making access to the study area difficult. This high energy environment may distinguish the area from reef sedimentary environments previously described. For example, the turbulence probably minimizes deposition of organic matter from the reef into the sediments, which should be reflected in the occurrence of oxidized sediments, low concentrations of inorganic nitrogen dissolved in sediment pore waters, and low rates of nitrogen remineralization and fluxes from the sediments. Specific objectives were to (1) determine the distribution of inorganic nitrogen in the sediments and (2) measure directly the rates of ammonium production and the release of ammonium and nitrate + nitrite from the sediments.

\section{METHODS}

In April 1982, 2 line transects marked every meter were set across the bottom in 1.2 to $3 \mathrm{~m}$ of water. The transects, selected because they paralleled deep natural indentations of the barrier reef, ran perpendicular to the landward edge of Tague Bay barrier reef, St. Croix (Fig. 1), ending at the boundary of the lagoon. One transect (T1) was $59 \mathrm{~m}$ long and the other (T2) was $24 \mathrm{~m}$ long. T2 was situated ca $20 \mathrm{~m}$ east of T1. Dupli- cate sampling stations were situated within $30 \mathrm{~cm}$ of each other every $2 \mathrm{~m}$ along the transects. T1 was set up again in December 1983 to select sites for the benthic nitrogen regeneration studies to follow.

Sediment analyses. A thin stiff wire probe was used to determine the depth of the unconsolidated sediments. The top $10 \mathrm{~cm}$ or less of sediment were collected using $50 \mathrm{ml}$ syringe corers and analysed for grain-size (Folk 1974). Sedimentary organic carbon (OC) was measured in the top $2 \mathrm{~cm}$ of sediment taken from another set of syringe cores, using a dichromate oxidation method (Gaudette et al. 1974). This method appears to be accurate to $<0.1 \%$ organic carbon, with no observable calcium carbonate interference determined using serial dilutions of OC standards (Gill 1983)

Sediment pore-water analyses. Miniature diffusion chambers were used to sample sediment pore-waters because centrifugation yielded insufficient quantities of fluid for analysis. These chambers were plastic containers $3.7 \mathrm{~cm}$ in diameter holding $50 \mathrm{ml}$ of filtered sea water. A $0.2 \mu \mathrm{m}$ Nuclepore filter was secured over the top. Duplicate chambers were buried in the top $5 \mathrm{~cm}$ of sediment and allowed to remain $14 \mathrm{~d}$. Equilibration times were determined in the laboratory using $0.2,3$, and $5 \mu \mathrm{M}$ nitrate solutions of artificial seawater (Strickland \& Parsons 1972) and also verified in the field by placing a series close together and sampling 2 chambers every $2 \mathrm{~d}$ for $18 \mathrm{~d}$.

Chambers were transported in a cooler to the laboratory where redox potential (Eh) followed by $\mathrm{pH}$ were determined immediately using an Orion Ionanalyzer Model 1390A with Model 96-78 platinum and Model 91-05 combination pH electrodes (Whit- 
field 1971). Meter readings (mV) stabilized within $15 \mathrm{~s}$ and values were corrected for the potential of the reference electrode. Ammonium (Koroleff 1976) and nitrate + nitrite (Strickland \& Parsons 1972) concentrations were determined by colorimetry. If the uncorrected Eh reading was $<100 \mathrm{mV}$, samples were acidified, degassed with $\mathrm{N}_{2}$ for $10 \mathrm{~min}$ and readjusted to the original $\mathrm{pH}$ before adding reagents to eliminate interference by $\mathrm{H}_{2} \mathrm{~S}$ in colorimetry.

Benthic nitrogen fluxes. Fluxes of ammonium and nitrate + nitrite were measured along T1 from 13 to $42 \mathrm{~m}$ away from the reef under diver-installed opaque PVC chambers. Measurements were started at 0900 to $1100 \mathrm{~h}$ on 9 to 18 January 1984. The chambers enclosed $0.049 \mathrm{~m}^{2}$ of sediment and 8 to $11 \mathrm{l}$ of overlying water stirred by bar magnets driven by batterypowered motors. Chambers were installed with lids removed to minimize sediment resuspension in areas free of visible biota. When flux measurements were repeated on the same area of sediment, the chambers were not disturbed, but the lids were removed for 5 min to allow exchange with ambient seawater. Initial water samples were withdrawn from a sampling port using a $30 \mathrm{ml}$ plastic syringe $2 \mathrm{~min}$ after the lids were in place. Ambient seawater replaced sampled water through an opened inflow port. Samples were taken subsequently at 2,4 , and $24 \mathrm{~h}$. This time course was selected on the basis of the magnitude of the fluxes in 7 preliminary experiments and sample processing time.

Duplicate samples were filtered using Gelman type AE glass-fiber filters in the field where ammonium reagents were added and the samples were kept cool and dark until transported to the laboratory. Duplicate nitrate + nitrite samples were filtered in the field, kept $\mathrm{cool}$ and dark and analyzed in the laboratory within $7 \mathrm{~h}$. Fluxes of ammonium and nitrate + nitrite were calculated as the slope of the line of concentration versus time using chamber volumes and areas for unit area conversion. We estimated that a $10 \%$ error is associated with this method, by calculating the maximum effect errors in chamber volume measurement and dilution by ambient seawater would have on the measured fluxes.

Ammonification experiments. An ammonification experiment was started on 10 January 1984 and again on 19 January. Sediment was collected using $50 \mathrm{ml}$ plastic syringe corers and $3 \mathrm{~cm}$ diameter PVC core tubes to a maximum depth of $10 \mathrm{~cm}$ but average of $\leq 5 \mathrm{~cm}$ along $\mathrm{T} 1$ near the sites of the flux measurements. Cores were kept cool and brought back to the laboratory within $1 \mathrm{~h}$ of collection. Sediment was extruded from the cores, mixed by hand, and placed in a $\mathrm{N}_{2}$-filled glove bag. The sediment slurries were placed in $50 \mathrm{ml}$ opaque glass test tubes which were capped tightly. The caps were sealed with black electrical tape. Test tubes were incubated at in situ temperature $\left(26^{\circ} \mathrm{C}\right)$ in the laboratory. Subsamples were retained for determination of the initial pore-water concentrations and porosity, as described below

Six tubes were sampled each 6 times during 5 weeks. Pore-water for ammonium analysis was separated from sediments by centrifugation. A portion of the centrifuged pellet was weighed wet and placed in a $50 \mathrm{ml}$ plastic centrifuge tube with $25 \mathrm{ml}$ of $2 \mathrm{~N} \mathrm{KCl}$ added to extract adsorbed ammonium (Rosenfeld 1979). These tubes were shaken every $10 \mathrm{~min}$ for $30 \mathrm{~min}$, centrifuged, and the $\mathrm{KCl}$ was decanted for ammonium analysis. Appropriate dilutions were made to keep analyses within the limitations of Beer's law.

Sediment porosity is defined as the ratio of volume of water to volume of wet sediments. Porosities of centrifuged and uncentrifuged sediments were calculated using the weight loss of wet sediment upon drying at $90^{\circ} \mathrm{C}$ and assuming an average carbonate sediment density of $2.84 \mathrm{~g} \mathrm{~cm}^{-3}$ (Milliman 1974). The net rate of ammonium production is defined as the product of $m$ times porosity, where $m$ is the slope of the regression of pore water concentrations in the incubated sediments against time. Ammonium concentration in pore water was regressed against concentration of ammonium per $\mathrm{g}$ dry sediment in order to determine the ammonium adsorption constant $\mathrm{K}^{*}$ (Rosenfeld 1979) and the unitless linear adsorption coefficient K (Krom \& Berner 1980, Mackin \& Aller 1984).

Statistical methods were after Sokal \& Rohlf (1969).

\section{RESULTS}

\section{Sediment analyses}

The backreef pavement was covered by a thin veneer of sediments. Mean depth to hard substratum was $8.9(8.4)^{\cdots} \mathrm{cm}, 20 \mathrm{~cm}$ maximum. Depths of unconsolidated sediments were less than $5 \mathrm{~cm}$ in the first $11 \mathrm{~m}$ next to the reef. Mean grain sizes ranged from 0.58 to $2.24 \phi$ (coarse to fine sands). In general, sediments became progressively finer away from the reef (Fig. 2).

Organic carbon varied along the transects from 0.19 to $0.59 \%$ dry weight with a mean of $0.34 \%(0.13)$ $(\mathrm{n}=22)$. Sedimentary OC showed no correlation with grain-size (correlation coefficient, $r=0.12$ ) or distance from the reef $(r=0.23)$. Observations during sampling suggested no obvious relationship between macrobenthic cover and organic accumulation.

\footnotetext{
- Mean values followed by 1 standard deviation unit (in parentheses) are used throughout the text.
} 


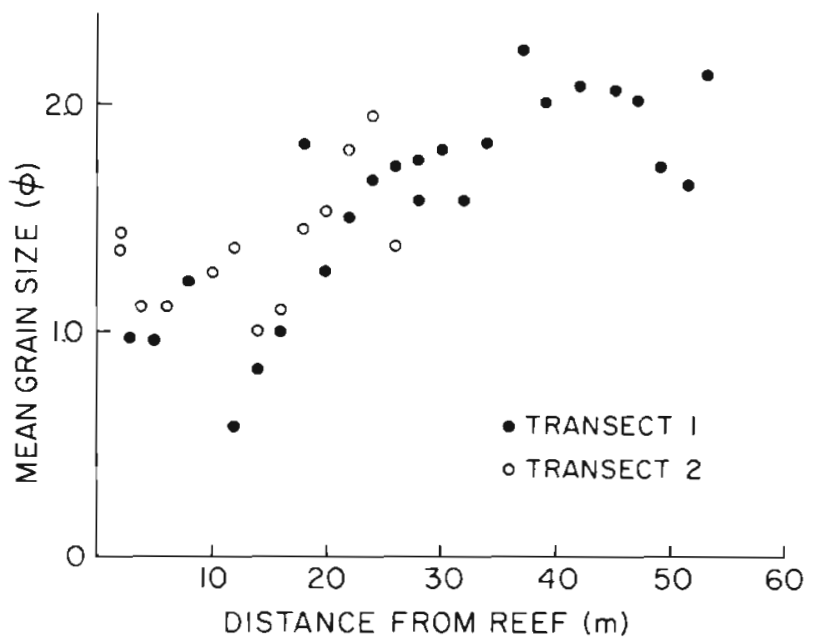

Fig. 2. Mean grain size of Tague Bay backreef sediments versus distance along transects, April 1982

\section{Sediment pore-water analyses}

Redox potential (Eh) of sediment pore-waters ranged from -180 to $+499 \mathrm{mV}$ and $\mathrm{pH}$ from 7.3 to 8.1 . These values fell into 2 basic groups, viz. $67 \%$ of the sampling sites were oxidized (Eh $>+300$ ) and the rest were reducing $(\mathrm{Eh}<0 \mathrm{mV})$. Eh correlated poorly with grain size $(\mathrm{r}=0.01), \mathrm{OC}(\mathrm{r}=0.14)$, and position on the transects $(r=0.08)$. Sediments on T1 were less reduced in December 1983 than in April 1982; Eh values were $\geq+49 \mathrm{mV}$ in December, when sea states were higher.

There were no significant differences in dissolved inorganic nitrogen concentrations in sediment porewaters between the transects in 1982 or between 1982 and 1983 for $\mathrm{T} 1$ (probability level $\mathrm{p}>0.90$ ). Concentrations were low; $83 \%$ of the nitrate + nitrite and $60 \%$ of the ammonium samples were less than $5 \mu \mathrm{M}$ (Fig. 3). Mean concentrations were 2.78 (2.58) $\mu \mathrm{M}$ nitrate + nitrite and 10.0 (14.9) $\mu \mathrm{M}$ ammonium, rang-
Table 1. Benthic nitrogen flux rates in Tague Bay backreef sediments, St. Croix, January 1984. Fluxes measured using benthic chambers. Flux predicted from mean ammonification rate, assuming steady state conditions and a $5 \mathrm{~cm}$ production zone. n: sample size; $\overline{\mathrm{X}}$ : mean; s.d.: one standard deviation

\begin{tabular}{|lrrrr|}
\hline & \multicolumn{4}{c}{ Flux rate $\left(\mu \mathrm{mol} \mathrm{m}^{-2} \mathrm{~h}^{-1}\right)$} \\
& $\mathrm{n}$ & $\overline{\mathrm{X}}$ & s.d. & Range \\
\hline Measured $\mathrm{NH}_{4}^{+}$flux & 24 & 71 & 95 & -90 to +372 \\
Predicted $\mathrm{NH}_{4}^{+}$flux & 2 & 107 & 62 & +96 to +194 \\
Meas. $\mathrm{NO}_{3}^{-}+\mathrm{NO}_{2}^{-}$flux & 12 & -5 & 40 & -131 to +141 \\
\hline
\end{tabular}

ing from 0 to 40 and 0 to 79 respectively. Ammonium concentrations were correlated inversely with Eh (Fig. 4). Ammonium and nitrate + nitrite were not inter-correlated $(\mathrm{r}=0.11)$ and both were uncorrelated with $O C(r \leq 0.28)$. Sites within less than $30 \mathrm{~cm}$ of each other could vary by as much as $30 \mu \mathrm{M}$.

\section{Benthic nitrogen fluxes}

A total of 24 measurements of benthic nitrogen fluxes were made. Pore-water concentrations in the areas studied ranged from 1 to $31 \mu \mathrm{M}$ ammonium and 0 to $1 \mu \mathrm{M}$ nitrate + nitrite. Eh of pore-water ranged from +49 to $+289 \mathrm{mV}$. Ammonium fluxes from the sediments were positive except for 3 cases where there was no net flux and 2 in which ammonium concentrations declined in the chambers. Ammonium fluxes were highly variable, ranging from -90 to $372 \mu \mathrm{mol}$ $\mathrm{N} \mathrm{m}^{-2} \mathrm{~h}^{-1}$ (Table 1). Fluxes measured over the same sediment area over consecutive days varied typically by $40 \mu \mathrm{mol} \mathrm{N} \mathrm{m} \mathrm{N}^{-2} \mathrm{~h}^{-1}$ but up to 150 in 1 case. Examples of various experiments are presented in Fig. 5.

The slope of the line of ammonium concentration versus time in the first $6 \mathrm{~h}$ was greater than the slope over $24 \mathrm{~h}$ in several cases. In these cases, if the final concentration in the chamber changed the sedimentwater diffusion gradient by over $15 \%$, we considered

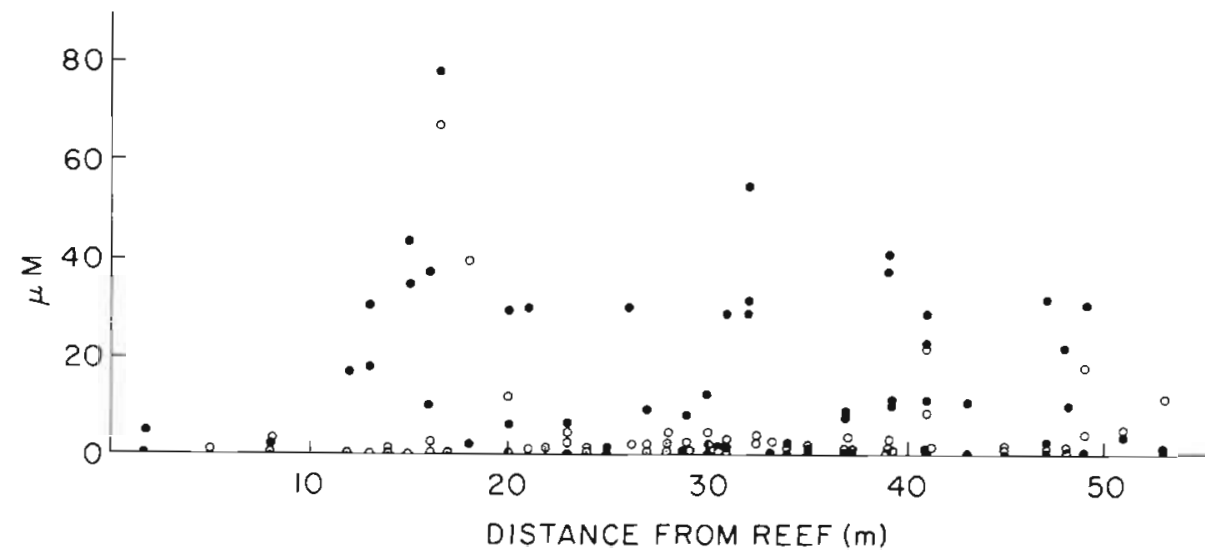

Fig. 3. Concentrations of dissolved inorganic nitrogen in porewaters of Tague Bay backreef sediments. Closed circles: ammonium; open circles: nitrate + nitrite 


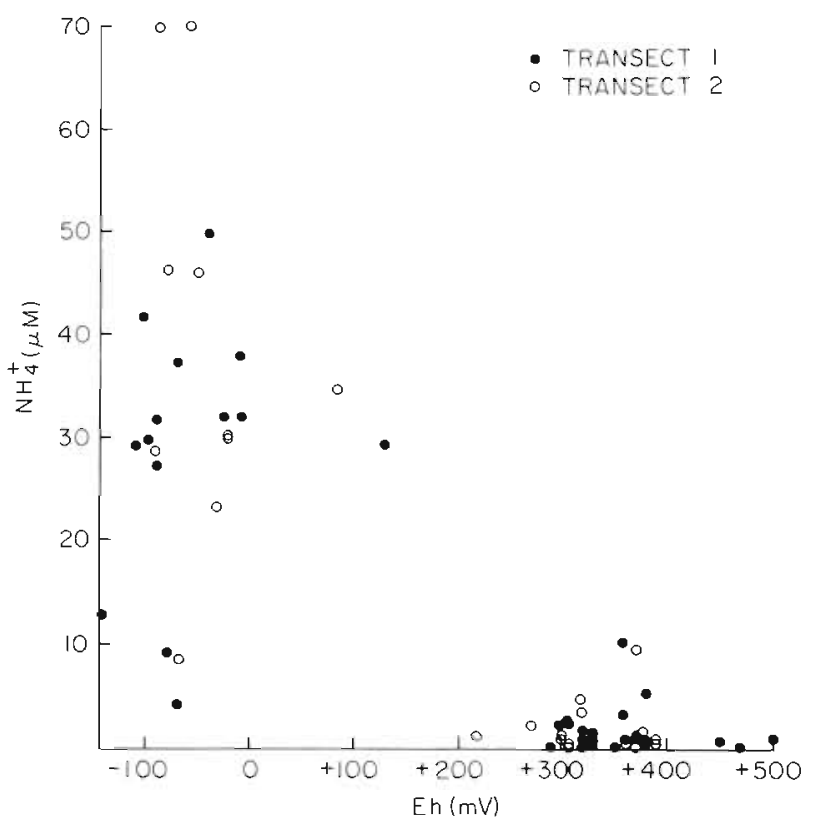

Fig. 4. The relation between pore-water ammonium and Eh in Tague Bay backreef sediments, April 1982
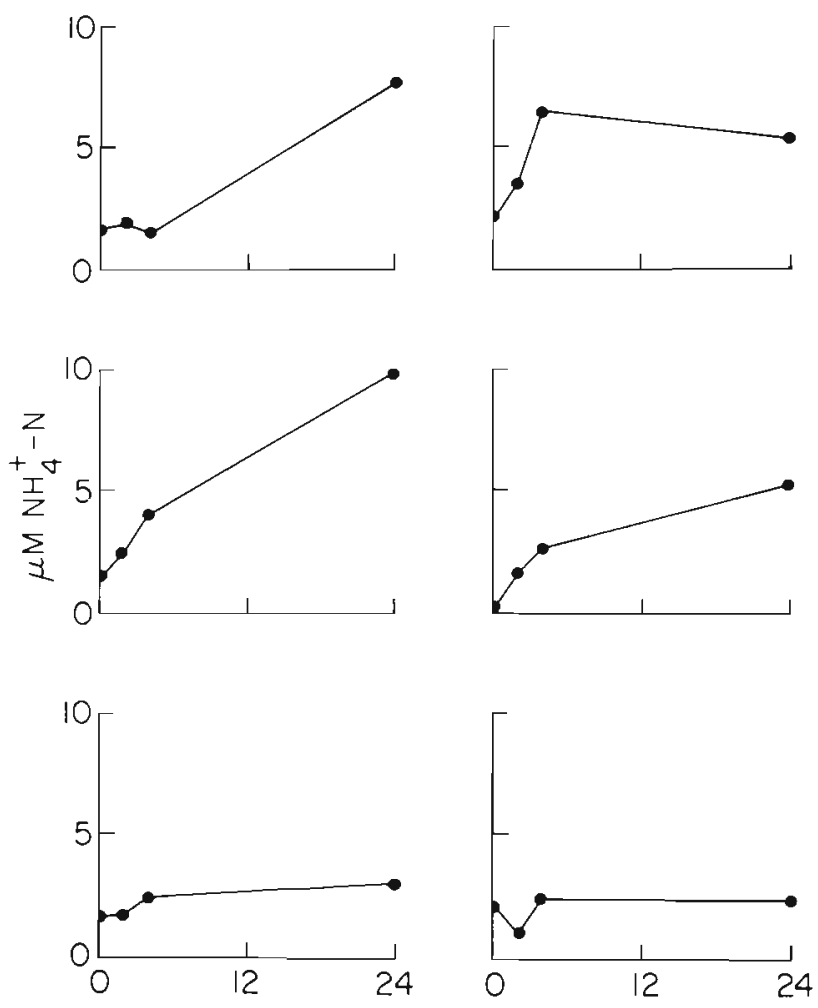

TIME (h)

Fig. 5. Examples of changes in ammonium concentration over time in benthic flux chambers, January 1984

the slope over $24 \mathrm{~h}$ to be an experimental artifact and included only the initial slope in the mean. In all other cases, we had no basis for ruling out intrinsic diurnal variation and included the $24 \mathrm{~h}$ slope in the mean.
Changes in nitrate + nitrite concentrations during an experiment were more erratic than those in ammonium. In half of the 24 experiments, concentrations fluctuated irregularly over time. We report only the experiments during which there was a clear increase or decrease in concentration over time (Table 1). Three of these cases were negative, indicating uptake of nitrate and nitrite by the sediments.

\section{Ammonification}

The net rate of ammonium production was 70 (33) $\mu$ mol (l sediment) ${ }^{-1} d^{-1}$ (Fig. 6). Due to curvature of the production line in the experiment begun 10 January 1984 , rates were calculated using only $11 \mathrm{~d}$ of data. We considered the initial portion of the curve representative of the actual rate because a decline in the rate over time, indicating possible OC substrate limitation, is reasonable given the low sedimentary $O C$ available. Of course, the alternative exists that the initial rate overestimates the actual rate due to a possible entombment of an organic-rich source in the test tubes. If all data were used, the mean would be 41 (9) $\mu \mathrm{mol}$ (1 sediment) ${ }^{-1} \mathrm{~d}^{-1}$, indicating the magnitude of an error in the assumption is small. At the low porewater concentrations found in the backreef sediments, ammonium adsorption to sediments was negligible (Fig. 7). Values of the adsorption coefficients were $\mathrm{K}^{*}=0.12(0.10) \mathrm{ml} \mathrm{g}^{-1}$ and unitless $\mathrm{K}=0.2(0.1)$ These values are very low compared to those from other marine sediments but not unreasonable given the low pore-water concentrations and the low adsorption capacity of carbonate sediments (Mackin \& Aller 1984). The ammonification rates, therefore, were uncorrected for ammonium adsorption.

Ammonium turnover times were calculated from the ammonification rate, porosity, and pore-water concentrations, assuming a steady state condition. Turnover times ranged from 0 to $0.74 \mathrm{~d}$ with a mean of $0.09 \mathrm{~d}$ (0.14). Of the sites sampled, $60 \%$ had turnover times less than $0.05 \mathrm{~d}$.

\section{DISCUSSION}

Tague Bay backreef sediments are a spatially heterogeneous environment of generally low dissolved-nitrogen pools but containing local pockets of reducing sediments with high ammonium concentrations. Spatial heterogeneity of the order of $\mathrm{cm}^{2}$ in Tague Bay backreef sediments was revealed by the high variability in all parameters measured except grain size, which varied regularly along the transects. No other parameter correlated with grain size. Sedi- 


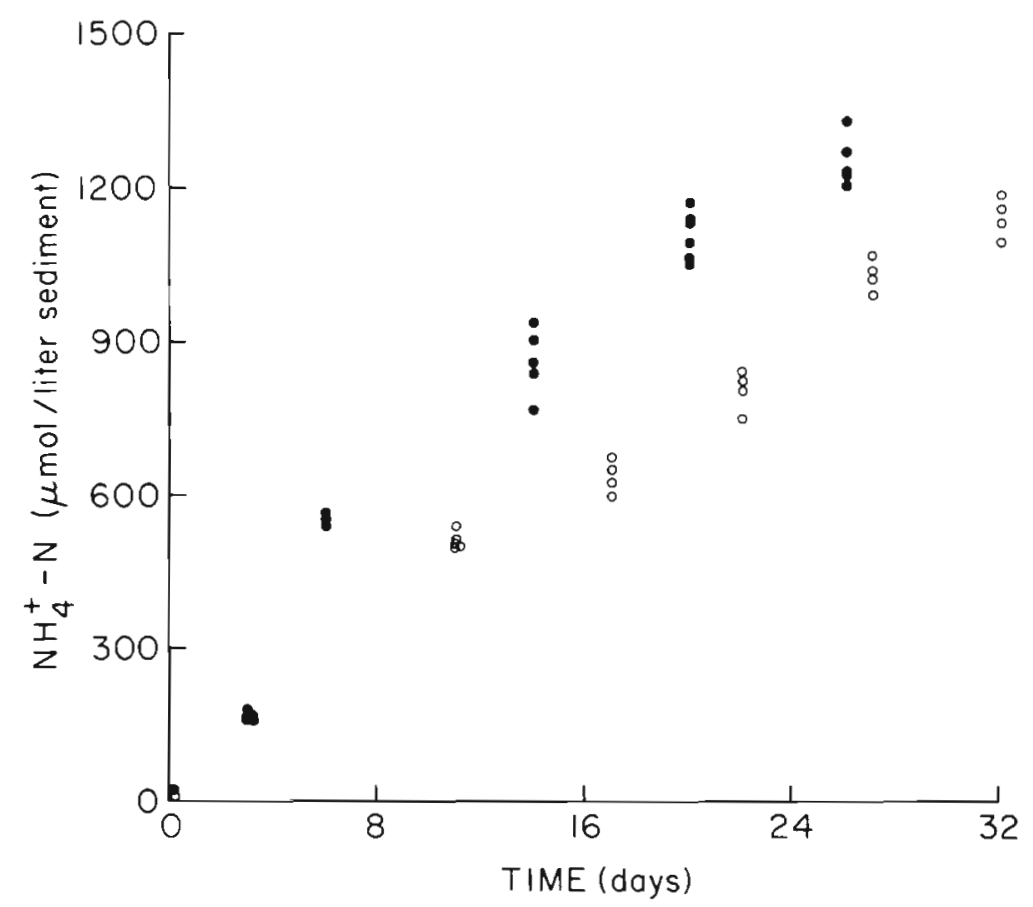

Fig. 6. Changes in ammonium per liter of Tague Bay backreef sediments versus time in 2 ammonification experiments. Experiments began 10 January 1984 (closed circles) and 19 January 1984 (open circles)

ment nitrogen pools in this backreef were similar to those reported from various reef sites (Pigott 1977. Hines \& Lyons 1982, Entsch et al. 1983). Benthic nitrogen fluxes were higher than those reported from Enewetak lagoon (Harrison 1983) and from sites impacted by sewage outfall in Hawaii (Dollar 1983), but in the lower range of values reported from many temperate coastal areas (Klump \& Martens 1983).

Although there was a wide range of pore-water inorganic nitrogen concentrations, most sampling sites had concentrations less than $5 \mu \mathrm{M}$. Factors serving to maintain low sediment concentrations are low inputs of organic matter, and efficient recycling. We did not measure organic inputs directly but the sediments appeared free of visible organic matter, organic carbon was $<0.6 \%$, and the high energy environment of the backreef is unlikely to promote deposition and accumulation of organic matter.

Ammonification rates reported here for the backreef sediments fall among the lower values measured in primarily silici-clastic anoxic sediments (Blackburn 1979, Klump \& Martens 1983), or modelled for carbonate sediment (Hines \& Lyons 1982). Ammonification rates on the backreef may be limited by organic input to the sediment. Organic substrate limitation is one possible cause of the slight decrease in rate after $7 \mathrm{~d}$ in

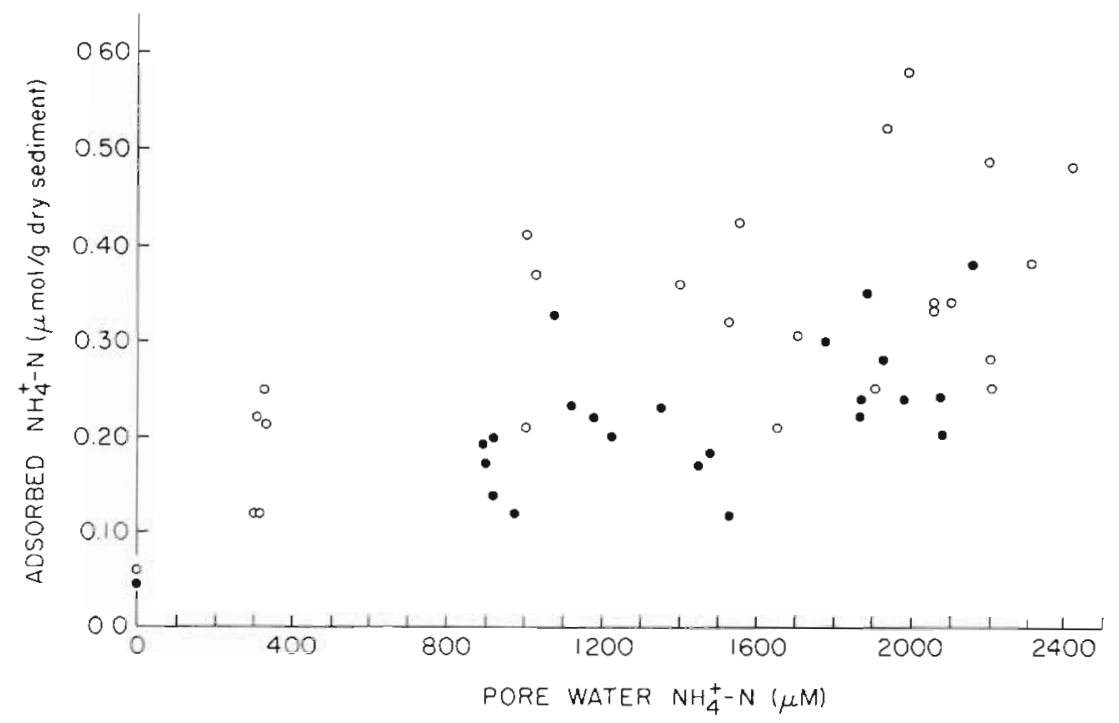

Fig. 7. Ammonium adsorption by Tague Bay backreef sediments. Symbols as in Fig. 6 
1 ammonification experiment (Fig. 6). Nonetheless, because of small pool sizes, the turnover of pore-water ammonium occurred many times daily.

Comparison of direct measurements of benthic fluxes with diffusion- and production-predicted analyses allows intercomparison of methods and can provide insight on recycling processes (Aller 1980). We did not calculate a diffusion-predicted flux because we were unable to sample pore-waters at close enough depth intervals to give an adequate concentration gradient. A production-predicted benthic flux can be calculated from the ammonification rate by assuming that ammonium production is equal to the amount diffusing from the sediments at steady state (Aller 1980). An average production depth of $5 \mathrm{~cm}$ yielded a production-predicted flux of $107 \mu \mathrm{mol} \mathrm{N} \mathrm{m}^{-2} \mathrm{~h}^{-1}$. Given the assumptions of the calculation and errors in direct measurements, the production-predicted flux falls within the range of measured fluxes (Table 1). The sediments for the ammonification experiments were taken from many small areas in the sites of flux measurements and were mixed together. The flux predicted from the ammonification experiment is in essence a rough approximation of the areas of sediment enclosed under the chambers, which had much larger diameters than the core tubes. The production rate and thus predicted flux, however, may be overestimated because net nitrogen mobilization may have been increased under our anaerobic experimental conditions (Otsuki \& Hanya 1972, Parnas 1975).

Although the mean measured ammonium flux is similar to the production-predicted flux, the wide range of fluxes must be considered. In addition to indicating spatial heterogeneity, departures from the production-predicted flux could point to processes occurring in addition to ammonification which apparently maintains the flux across the sediment-water interface. Negative fluxes might indicate uptake of ammonium by the enclosed plankton and benthos and nitrification in the upper mm's of sediment or overlying waters. Opaque chambers would minimize but not prevent ammonium uptake by primary producers (MacIsaac \& Dugdale 1972, Hanisak 1984). The occurrence of lower-than-predicted fluxes suggests, in addition to benthic uptake or overestimation of ammonification, that the ammonium produced could be lost to nitrification, possibly coupled to denitrification. The $\mathrm{pH}$ and $\mathrm{Eh}$ conditions in the sediments were within the environmental limits of denitrifying bacteria (Baas Becking et al. 1960) and recent work has demonstrated that denitification can occur contemporaneously with nitrification (Jenkins \& Kemp 1984). We have some indirect evidence for the occurrence of denitrification. There was no correlation between ammonium and nitrate + nitrite fluxes or between pore-water ammonium and nitrate + nitrite. Assuming nitrification solely accounted for the lower-than-predicted ammonium fluxes and denitrification did not occur, enhanced nitrate fluxes should have been associated with ammonium fluxes lower than predicted. Admittedly, a great deal of confidence should not be placed on these comparisons, given the degree of error associated with the measurements and the assumptions. Rather, these comparisons indicate the potential for denitrification in Tague Bay backreef sediments. If denitrification does occur, then direct measurement of the loss of nitrogen from the coral reef ecosystem should become a research priority.

The occurrence of higher-than-predicted fluxes could indicate excretion by the benthos. Alternatively, higher-than-predicted fluxes may have occurred locally in regions of high nitrogen mobilization, which could be possible in local areas of reducing sediments with concentrations $>30 \mu \mathrm{MN}$. Such reducing sediments were found scattered along the transects and were present in only $2 \mathrm{~cm}$ of sediment depth, where the downward diffusion of oxygen and the tendency for complete resuspension would be maximized. The occurrence of high ammonium/low Eh conditions is surprising given the turbulence of the backreef, particularly close to the reef framework where hydraulically induced ripples are common. There was no obvious relationship between the distribution of these areas and growth of sediment-stabilizing algae such as Caulerpa and Halimeda. Low Eh and high ammonium concentrations did occur under a bloom of an unidentified Chrysophycean alga and often where the gelatinous filaments of Crouaniasp., a microscopic red alga, tended to bind sediment grains. These observations suggest microalgae may stabilize the sediments and allow formation of zones wherein the rate of diffusion or production of oxygen is lower than that of benthic community respiration and enhanced nitrogen remineralization may occur. Depending on the specific conditions in the sediments, nitrification coupled to denitrification could also occur in these areas.

In summary, our initial impression that the physical regime of Tague Bay backreef sediments would define a region of low organic input to the sediment was supported by the data; sediments were mostly oxidized, and had relatively low organic carbon, porewater nitrogen pools, and rates of ammonification and dissolved inorganic nitrogen fluxes. The occurrence of local pockets of higher ammonium concentrations in reducing sediments and the possible role of microalgae in fostering the development of these conditions through sediment stabilization is intriguing. These sediments may be areas of enhanced nitrogen remineralization and possibly a loss of nitrogen through denitrification. The high degree of spatial 
heterogeneity observed in Tague Bay backreef sediments calls for an even smaller sampling scale than was used. Given our difficulty in sampling pore waters in sediment depth intervals small enough to allow construction of a diagenetic model, direct measurements of nitrification and denitrification will be important for future studies. The flux rates may be underestimated and the control of the fluxes by ammonification may be overemphasized considering the potential for physical mixing events, particularly in the stormy months November through January. Benthic chambers equipped to generate internal turbulence would be useful. A detailed description of the concentration gradient over depth would help to model turbulent mass transfer (Vanderborght et al. 1977).

Acknowledgements. This research was supported in part by Alexander Bache Fund of the National Academy of Science and by grant \#DEB-81-06991 of the National Science Foundation. T. Robinson helped to design and test the diffusion chambers and assisted with the preliminary work. Dr. D. C. Capone kindly loaned us the benthic chambers. We thank Drs. D. C. Capone, T. R. Fisher, and J. E. Mackin for providing discerning comments on the manuscript and Dr. C. F. D'Elia and an anonymous reviewer for their helpful remarks.

\section{LITERATURE CITED}

Adey, W. (1975). The algal ridges and coral reefs of St. Croix: their structure and Holocene development. Atoll Res. Bull. 187: $1-67$

Adey, W. (1978). Coral reef morphogenesis: a multidimensional model. Science 202: 831-837

Adey, W., Burke, R. (1976). Holocene bioherms (algal ridges and bank barrier reefs) of the eastern Caribbean. Bull. geol. Soc. Am. 87: 95-109

Aller, R. C. (1980). Diagenetic process near the sedimentwater interface of Long Island sound. I. Decomposition and nutrient element geochemistry ( $\mathrm{S}, \mathrm{N}, \mathrm{P})$. Adv. Geophys. 22 : $237-350$

Baas Becking, L. G. M., Kaplan, I. R., Moore, D. (1960). Limits of the natural environment in terms of $\mathrm{pH}$ and oxidationreduction potentials. J. Geol. 68: 243-284

Blackburn, T. H. (1979). Method for measuring rates of $\mathrm{NH}_{4}^{+}$ turnover in anoxic marine sediments, using ${ }^{15} \mathrm{~N}-\mathrm{NH}_{4}^{+}$dilution technique. Appl. environ. Microbiol. 33: 760-765

DiSalvo, L. H. (1974). Soluble phosphorus and amino nitrogen released to seawater during recoveries of coral reef regenerative sediments. Proc. Intl. Coral Reef Symp. 2: 11-19

Dollar, S. J. (1983). Contrasts in benthic ecosystem response to nutrient subsidy; community structure and function at Sand Island, Hawaii. In: Reaka, M. (ed.) The ecology of deep and shallow coral reefs, symp. series for undersea research, Vol. 1, No. 1, NOAA's Undersea Research Program, Rockville, Maryland, p. 141-144

Entsch, B. K., Boto, G., Sim, R. G., Wellington, J. T. (1983). Phosphorus and nitrogen in coral reef sediments. Limnol. Oceanogr. 28: $465-476$
Folk, R. L. (1974). Petrology of sedimentary rocks. Hemphill Austin, Texas

Gaudette, H. E., Flight, W. R., Toner, L., Folger, D. W. (1974) An inexpensive titration method for the determination of organic carbon in recent sediments. J. sedim. Petrol. 44: 249-253

Gill. I. (1983). Sedimentological controls on organic carbon distribution in the Virgin Islands trough. MS thesis, University of Rochester, Rochester, New York

Hanisak, M. D. (1984). The nitrogen relationships of marine macroalgae. In: Carpenter, E. J., Capone, D. G. (ed.) Nitrogen in the marine environment. Academic Press, New York, p. 699-730

Harrison, J. T. (1983). Metabolism of sediment communities. In: Reaka, M. (ed.) The ecology of deep and shallow coral reefs, symp. series for undersea research, Vol, 1, No. 1. NOAA's Undersea Research Program, Rockville, Maryland, p. 145-159

Hines, M. E., Lyons, W. B. (1982). Biogeochemistry of nearshore Bermuda sediments. I. Sulfate reduction rates and nutrient regeneration. Mar. Ecol. Prog. Ser. 8: 87-94

Jenkins, M. C., Kemp, W. M. Jr. (1984). The coupling of nitrification and denitrification in two estuarine sediments. Limnol. Oceanogr. 29: 609-619

Klump, J. V., Martens, C. S. (1983). Benthic nitrogen regeneration. In: Carpenter, E. J., Capone, D. G. (ed.) Nitrogen in the marine environment. Academic Press, New York, p. $411-457$

Koroleff, F. (1976). Determination of $\mathrm{NH}_{4}^{+}-\mathrm{N}$. In: Grasshoff, K. (ed.) Methods of seawater analysis. Verlag Chemie, Weinheim, p. 127-133

Krom, M. D., Berner, R. A. (1980). Adsorption of phosphate in anoxic marine sediments. Limnol. Oceanogr. 25: 797-806

MacIsaac, J. J., Dugdale, R. C. (1972). Interactions of light and inorganic nitrogen in controlling nitrogen uptake in the sea. Deep Sea Res. 19: 209-232

Mackin, J. E., Aller, R. C. (1984). Ammonium adsorption in marine sediments. Limnol. Oceanogr. 29: 250-257

Milliman, J. D. (1974). Marine carbonates. Springer-Verlag, New York

Otsuki, A., Hanya, T. (1972). Production of dissolved organic matter from dead algal cells. II. Anaerobic microbial decomposition. Limnol. Oceanogr. 17: 258-264

Parnas, H. (1975). Model for decomposition of organic material by microorganisms. Soil Biol. Biochem. 7: 161-169

Pigott, J. D. (1977). Early diagenesis of dissolved sulfur and nitrogen species in Jamaican reef sediments (determined by in situ sampling). Proc. Intl. Coral Reef Symp. 3: 533-538

Risk, M. J., Muller, H. R. (1983). Porewater in coral heads: evidence for nutrient regeneration. Limnol. Oceanogr. 28: $1004-1008$

Rosenfeld, J. K. (1979). Ammonium adsorption in nearshore anoxic sediments. Limnol. Oceanogr. 24: 356-364

Sokal, R. R., Rohlf, F. J. (1969). Biometry. W. H. Freeman, San Francisco

Strickland, J. D. H., Parsons, T. R. (1972). A practical handbook of seawater analysis. Bull. Fish. Res. Bd Can. 167

Vanderborght, J., Wollast, R., Billen, G. (1977). Kinetic models of diagenesis in disturbed sediments. Part 2. Nitrogen diagenesis. Limnol. Oceanogr. 22: 794-803

Whitfield, $M$. (1971). Ion selective electrodes for the analysis of natural waters. Handbook 2. Aust. Mar. Sci. Assoc., Sydney 